University of Nebraska - Lincoln

DigitalCommons@University of Nebraska - Lincoln

Water for Food Faculty Publications

Water for Food

2014

Fluoride Exposure from Groundwater as Reflected by Urinary Fluoride and Children's Dental Fluorosis in the Main Ethiopian Rift Valley

Tewodros Rango

DukeUniversity, tg67@duke.edu

Avner Vengosh

Duke University, vengosh@duke.edu

Marc Jeuland

DukeUniversity, marc.jeuland@duke.edu

Redda Tekle-Haimanot

Addis Ababa University

Erika Weinthal

Duke University, erika.weinthal@duke.edu

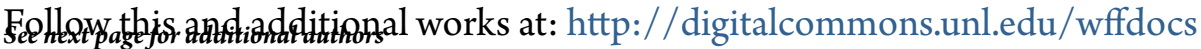

Part of the Environmental Health and Protection Commons, Environmental Monitoring Commons, $\underline{\text { Hydraulic Engineering Commons, Hydrology Commons, Natural Resource Economics }}$ Commons, Natural Resources and Conservation Commons, Natural Resources Management and $\underline{\text { Policy Commons, Sustainability Commons, and the Water Resource Management Commons }}$

Rango, Tewodros; Vengosh, Avner; Jeuland, Marc; Tekle-Haimanot, Redda; Weinthal, Erika; Kravchenko, Julia; Paul, Christopher; and McCornick, Peter G., "Fluoride Exposure from Groundwater as Reflected by Urinary Fluoride and Children's Dental Fluorosis in the Main Ethiopian Rift Valley" (2014). Water for Food Faculty Publications. 3.

http://digitalcommons.unl.edu/wffdocs/3

This Article is brought to you for free and open access by the Water for Food at DigitalCommons@University of Nebraska - Lincoln. It has been accepted for inclusion in Water for Food Faculty Publications by an authorized administrator of DigitalCommons@University of Nebraska - Lincoln. 


\section{Authors}

Tewodros Rango, Avner Vengosh, Marc Jeuland, Redda Tekle-Haimanot, Erika Weinthal, Julia Kravchenko, Christopher Paul, and Peter G. McCornick 
Published in Science of the Total Environment 496 (2014), pp. 188-197; doi: 10.1016/j.scitotenv.2014.07.048 Copyright (C) 2014 Elsevier B.V. Used by permission.

Submitted May 18, 2014; revised and accepted July 12, 2014; published online July 30, 2014.

Supporting information for this article is available following the references.

\title{
Fluoride Exposure from Groundwater as Reflected by Urinary Fluoride and Children's Dental Fluorosis in the Main Ethiopian Rift Valley
}

\author{
Tewodros Rango, ${ }^{1}$ Avner Vengosh, ${ }^{1}$ Marc Jeuland, ${ }^{2,7}$ \\ Redda Tekle-Haimanot, ${ }^{3}$ Erika Weinthal, ${ }^{4}$ Julia Kravchenko, ${ }^{5}$ \\ Christopher Paul, ${ }^{4}$ and Peter McCornick ${ }^{6}$
}

1. Division of Earth and Ocean Sciences, Nicholas School of the Environment, Duke University, Durham, North Carolina, USA

2. Sanford School of Public Policy and Duke Global Health Institute, Duke University, Durham, North Carolina, USA

3. Addis Ababa University, Faculty of Medicine, Addis Ababa, Ethiopia

4. Division of Environmental Sciences and Policy, Nicholas School of the Environment, Duke University, Durham, North Carolina, USA

5. Duke University Medical Center, Department of Surgery, Division of Surgical Science, Duke University, Durham, North Carolina, USA

6. International Water Management Institute, Colombo, Sri Lanka

7. Institute of Water Policy, National University of Singapore, Singapore

Corresponding author - T. Rango, telephone +1-919-949-8783, email tg67@duke.edu

\begin{abstract}
This cross-sectional study explores the relationships between children's $\mathrm{F}^{-}$exposure from drinking groundwater and urinary $\mathrm{F}^{-}$concentrations, combined with dental fluorosis (DF) in the Main Ethiopian Rift (MER) Valley. We examined the DF prevalence and severity among 491 children (10 to 15
\end{abstract}


years old) who are lifelong residents of 33 rural communities in which groundwater concentrations of $\mathrm{F}^{-}$cover a wide range. A subset of 156 children was selected for urinary $\mathrm{F}^{-}$measurements. Our results showed that the mean $\mathrm{F}^{-}$concentrations in groundwater were $8.5 \pm 4.1 \mathrm{mg} / \mathrm{L}$ (range: $1.1-18$ $\mathrm{mg} / \mathrm{L}$ ), while those in urine were $12.1 \pm 7.3 \mathrm{mg} / \mathrm{L}$ (range: $1.1-39.8 \mathrm{mg} / \mathrm{L}$ ). The prevalence of mild, moderate, and severe DF in children's teeth was $17 \%, 29 \%$, and $45 \%$, respectively, and the majority $(90 \% ; n=140)$ of the children had urinary $\mathrm{F}^{-}$concentrations above $3 \mathrm{mg} / \mathrm{L}$. Below this level most of the teeth showed mild forms of DF. The exposure-response relationship between $\mathrm{F}^{-}$and DF was positive and nonlinear, with DF severity tending to level off above a $\mathrm{F}^{-}$threshold of $\sim 6 \mathrm{mg} / \mathrm{L}$, most likely due to the fact that at $\sim 6 \mathrm{mg} / \mathrm{L}$ the enamel is damaged as much as it can be clinically observed in most children. We also observed differential prevalence (and severity) of DF and urinary concentration across children exposed to similar $\mathrm{F}^{-}$concentrations in water, which highlights the importance of individual-specific factors in addition to the $\mathrm{F}^{-}$levels in drinking water. Finally, we investigated urinary $\mathrm{F}^{-}$in children from communities where defluoridation remediation was taking place. The lower $\mathrm{F}^{-}$concentration measured in urine of this population demonstrates the capacity of the urinary $\mathrm{F}^{-}$method as an effective monitoring and evaluation tool for assessing the outcome of successful $\mathrm{F}^{-}$mitigation strategy in a relatively short time (months) in areas affected with severe fluorosis.

Keywords: drinking water quality, urinary biomarker, exposure-response, defluoridation, risk assessment, East Africa

\section{Introduction}

Globally, an estimated 200 million people are exposed to high concentrations of naturally occurring fluoride $\left(\mathrm{F}^{-}\right)$that exceeds the World Health Organization (WHO) guideline of $1.5 \mathrm{mg} / \mathrm{L}$ in drinking water (Ayoob and Gupta, 2006; WHO, 2006). This high exposure to $\mathrm{F}^{-}$leads to fluorosis - in its dental and skeletal forms - and is endemic in at least 25 countries, including India, China, Mexico, Brazil, Saudi Arabia, United States (U.S.), Uganda, Tanzania, and Ethiopia (WHO, 2006; Amini et al., 2008). High-risk areas are mostly located in arid and semiarid regions that are characterized by a rapid rate of chemical weathering of geological materials, such as the East African Rift System (EARS).

The EARS is a unique geological feature where active faulting has generated voluminous pyroclastic volcanic rocks (Chorowicz, 2005) that are highly reactive with local groundwater (Rango et al., 2013). This study focuses on the Main Ethiopian Rift (MER), which is located in the northern part of EARS, and where a large number of drinking water wells have been documented to contain high levels of naturally occurring contaminants such as F-, arsenic (As), and uranium (U) (Reimann et al., 2003; Rango et al., 2012, 2013). Systematic water testing in the Ziway-Shala basin of the MER has shown that $\mathrm{F}^{-}$concentrations can reach up to $68 \mathrm{mg} / \mathrm{L}$ (mean: $9.4 \pm 10.5 \mathrm{mg} / \mathrm{L}$ ), and that $\mathrm{F}^{-}$levels in $94 \%$ of the tested wells exceeded the World Health Organization (WHO) standard of $1.5 \mathrm{mg} / \mathrm{L}$ (Rango et al., 2012). In this region, an estimated 8.5 million people, mostly from rural communities, are highly dependent on groundwater resources for drinking and domestic purposes and are thus at risk of fluorosis (Tekle-Haimanot et al., 1987; Tekle-Haimanot, 2005; TekleHaimanot and Haile, 2014). 
Exposure to $\mathrm{F}^{-}$has two critical effects on the teeth. On the one hand, optimum intake of this element is critical for dental development; F- intake of $0.5-1 \mathrm{mg} / \mathrm{L}$ is recommended to achieve maximum protection against dental caries (U.S. DHHS, 1991; WHO, 2006). Indeed, fluoridation of community drinking water is considered a safe and effective means of preventing such caries and has been called one of the ten great public health achievements of the 20th century (U.S. CDC, 1999). On the other hand, excessive intake of $\mathrm{F}^{-}$from sources such as water, food, and fluoride-containing dental products is known to cause dental and skeletal fluorosis (DF and SF) (WHO, 2006). DF-the focus of this study -is a condition of subsurface enamel porosity that may progress to enamel pitting, followed by total enamel loss and secondary discoloration of the enamel surface (Fejerskov et al., 1996).

The severity of DF depends on the complex interplay of exposure, duration, and timing of $\mathrm{F}^{-}$intake and ingestion (Den Besten, 1994). It is particularly acute when children are exposed to high levels of $\mathrm{F}^{-}$in early childhood (typically at ages up to 4 years) (Fomon et al., 2000; U.S. CDC, 2001; Hong et al., 2006). To achieve dental protection without compromising health, the U.S. Environmental Protection Agency (EPA) has thus specified the optimal level of $0.06 \mathrm{mg} / \mathrm{kg}$ bw/day as the No-Observed-Adverse-Effects-Level (NOAEL) (U.S. EPA, 2002). The NOAEL is an estimate of the daily $\mathrm{F}^{-}$exposure that does not lead to cosmetic DF effects (brown staining and/or pitting of enamel) among children. For a $\mathrm{F}^{-}$ intake from drinking water through the consumption of $1 \mathrm{~L} /$ day by 12 - to 14-year-old children, the NOAEL corresponds to a concentration of about $1 \mathrm{mg} / \mathrm{L}$ of F- (U.S. EPA, 2002). The WHO guideline for drinking water is $1.5 \mathrm{mg} / \mathrm{L}$, but the guidelines note that when water intakes are high, for example in arid and semiarid settings, it may be appropriate to consider a local guideline concentration that is lower than $1.5 \mathrm{mg} / \mathrm{L}$ (WHO, 2006).

It is indisputable that $\mathrm{F}^{-}$in drinking water is the primary factor that causes DF; however, the precise exposure-response condition has not been well established, in part because of the difficulty of tracking varying exposures over long and critical periods of dental development. Previous studies, for example in the United States, have demonstrated a linear dose-response relationship at low- $\mathrm{F}^{-}$intakes, i.e., mostly below $4 \mathrm{mg} / \mathrm{L}$ from drinking water (U.S. NRC, 2006). Very few studies-e.g., Ruiz-Payan et al. (2005) (covering water sources $<5.7 \mathrm{mg} / \mathrm{L}$ in Mexico), Wang et al. (2012) $(<11 \mathrm{mg} / \mathrm{L}$, mostly below $7 \mathrm{mg} / \mathrm{L}$ in China), and Wondwossen et al. (2004) (including low (0.3-2.2 mg/L) and high F- (10-14 $\mathrm{mg} / \mathrm{L}$ ) concentrations of $\mathrm{F}^{-}$in the Ethiopian Rift Valley) - have considered the development of $\mathrm{DF}$ across a wide range of $\mathrm{F}^{-}$exposures in a specific geographic region. There are also challenges related to confounding by other sources of exposure: for example, existing studies from the MER have shown that food ingredients and food or beverages prepared with high F- water contribute significantly to total F- intake (Malde et al., 1997, 2003, 2004, 2011; Dessalegne and Zewege, 2013). Based on the available research evidence, the U.S. EPA established a MCLG (Maximum-Contaminant-Level Goal) threshold of $4 \mathrm{mg} / \mathrm{L}$ to protect from adverse health effects (crippling skeletal fluorosis) and a SMCL (Secondary-Maximum-Contaminant-Level) threshold of $2 \mathrm{mg} / \mathrm{L}$ of $\mathrm{F}^{-}$to protect from adverse cosmetic effects (moderate and/or severe DF) (U.S. NRC, 2006). Yet it is not clear whether the $\mathrm{F}^{-}$ exposure thresholds established by the U.S. EPA, or by the WHO, are valid or applicable in other countries with different climates, exposure sources and pathways, and population characteristics, such as those in Ethiopia. 
In this paper, we describe the results of an exposure-response study of the effects of $\mathrm{F}^{-}$ that was conducted in the MER. The study builds on prior work in the same region that considered the relationship between F- in groundwater and DF (Rango et al., 2012) by more carefully: (1) specifying the full range of $\mathrm{F}^{-}$concentrations in groundwater encountered in this region; (2) restricting the sample to the specific age range (10 and 15 years) of children; (3) limiting threats related to confounding by including only individuals who are lifelong residents of rural communities in which the primary community drinking water supplies were installed before the children were born; and (4) generating new data on urinary $\mathrm{F}^{-}$ concentration and establishing their relationship with exposures to $\mathrm{F}^{-}$in groundwater and DF severity. Because of the temporal stability and spatial variability in $\mathrm{F}^{-}$levels across communities (ranging from 1.1 to $18 \mathrm{mg} / \mathrm{L}$ ) in these sources the study of this population provides us a unique opportunity to make inferences about the relationship between exposure and health effects over a wide range of $\mathrm{F}^{-}$concentrations. Working with this population, we investigated whether there might be thresholds for drinking water $\mathrm{F}^{-}$ concentrations for either minimal or severe DF.

Our study contributes to a relatively limited literature that examines the relationship between $\mathrm{F}^{-}$levels measured in drinking water and urine among a subset of study subjects and is one of the only ones to consider such a wide range of $\mathrm{F}^{-}$exposures. In the human body, approximately $99 \%$ of the $\mathrm{F}^{-}$is stored in calcified tissues (i.e., bones and teeth) (Whitford, 1996). Roughly $30-50 \%$ of the $\mathrm{F}^{-}$absorbed every day by young to middle-aged adults is assimilated within $24 \mathrm{~h}$ by calcified tissues as compared to about $80 \%$ by young children, and the remainder is predominantly excreted in the urine (Ekstrand et al., 1994; Whitford, 1996). Prolonged exposure to steady and high concentrations of $\mathrm{F}^{-}$can yield urinary $\mathrm{F}^{-}$ excretion above $80 \%$ of the total $\mathrm{F}^{-}$intake, particularly when mineralized tissues are close to saturation with $\mathrm{F}^{-}$(Myers, 1978). Based on this premise, we supplemented analyses of drinking water and DF examinations with measures of urinary $\mathrm{F}^{-}$concentrations, in order to more adequately monitor recent $\mathrm{F}^{-}$exposure (Whitford, 1994; Singh et al., 2007; Srikanth et al., 2013). We also evaluated urinary $\mathrm{F}^{-}$concentrations in a community with an active pilot defluoridation intervention to provide an initial understanding of the short-term effect of defluoridation on this biomarker. To date, studies have largely been conducted in areas with either exclusively low (e.g., Czarnowski et al., $1996(<1.2 \mathrm{mg} / \mathrm{L})$; Heintze et al., 1998 (<1.3 mg/L); Villa et al., $2000(<0.6 \mathrm{mg} / \mathrm{L})$; Forte et al., $2008(<1.5 \mathrm{mg} / \mathrm{L})$; Zohouri and Rugg-gunn, 2000 (<0.4 mg/L); Ding et al., 2011 (<3 mg/L); Zohouri et al., 2013 (< 1.06 $\mathrm{mg} / \mathrm{L}$ )) or high F- in drinking water (e.g., Ruiz-Payan et al., 2005 (up to $5.7 \mathrm{mg} / \mathrm{L}$ ); Wang et al., 2012 (mostly below $7 \mathrm{mg} / \mathrm{L}$ )).

The present study thus provides more comprehensive evidence on the effects of a wide range of exposures to $\mathrm{F}^{-}$on $\mathrm{DF}$ than the majority of existing studies. The study population from the MER was found to be an ideal research group for these exposure-response investigations because of the relative homogeneity of the population being studied (in terms of diet, ethnicity, and rural location), its high reliance on specific groundwater sources for drinking water in which concentrations of $\mathrm{F}^{-}$are temporally stable, and the low potential for confounding given the limited ingestion of other products containing $\mathrm{F}^{-}$, such as industrial (e.g., processed diet and soft drinks) or topical (e.g., toothpaste) products. Finally, our 
analyses also consider the role of potential modifiers (such as sex, age, nutritional status, and breastfeeding history) to DF outcomes.

\section{Materials and methods}

\subsection{Field measurements}

\subsubsection{Measurement of $F^{-}$in groundwater}

Groundwater samples were collected from 94 community wells during the dry season (April-May 2010, March 2011, and November 2012) (Fig. 1). The samples were collected from active pumping wells that were primarily used for drinking water. Water was allowed to flow for a few minutes from wells prior to sampling. The $\mathrm{F}^{-}$concentration in groundwater was measured in-situ and determined electrochemically using the Thermo Scientific Orion Ion-Selective Electrode (ISE) (results were confirmed using the Ion Chromatography method) following a procedure reported by Singh et al. (2007) and Ruiz-Payan et al. (2005). The water samples were diluted with equal volume ratio with a total ionic strength adjustment buffer (TISAB II) of $\mathrm{pH} 5-5.5$, which allows for optimal analyses of $\mathrm{F}^{-}$ in aqueous solution. Calibration standards were prepared from $100 \mathrm{mg} / \mathrm{L}$ stock solution. The mean electrode calibration slope for a 10-fold change in $\mathrm{F}^{-}$concentration was $-58.4 \pm$ $0.6 \mathrm{mV}$, which is within acceptable theoretical slope range.

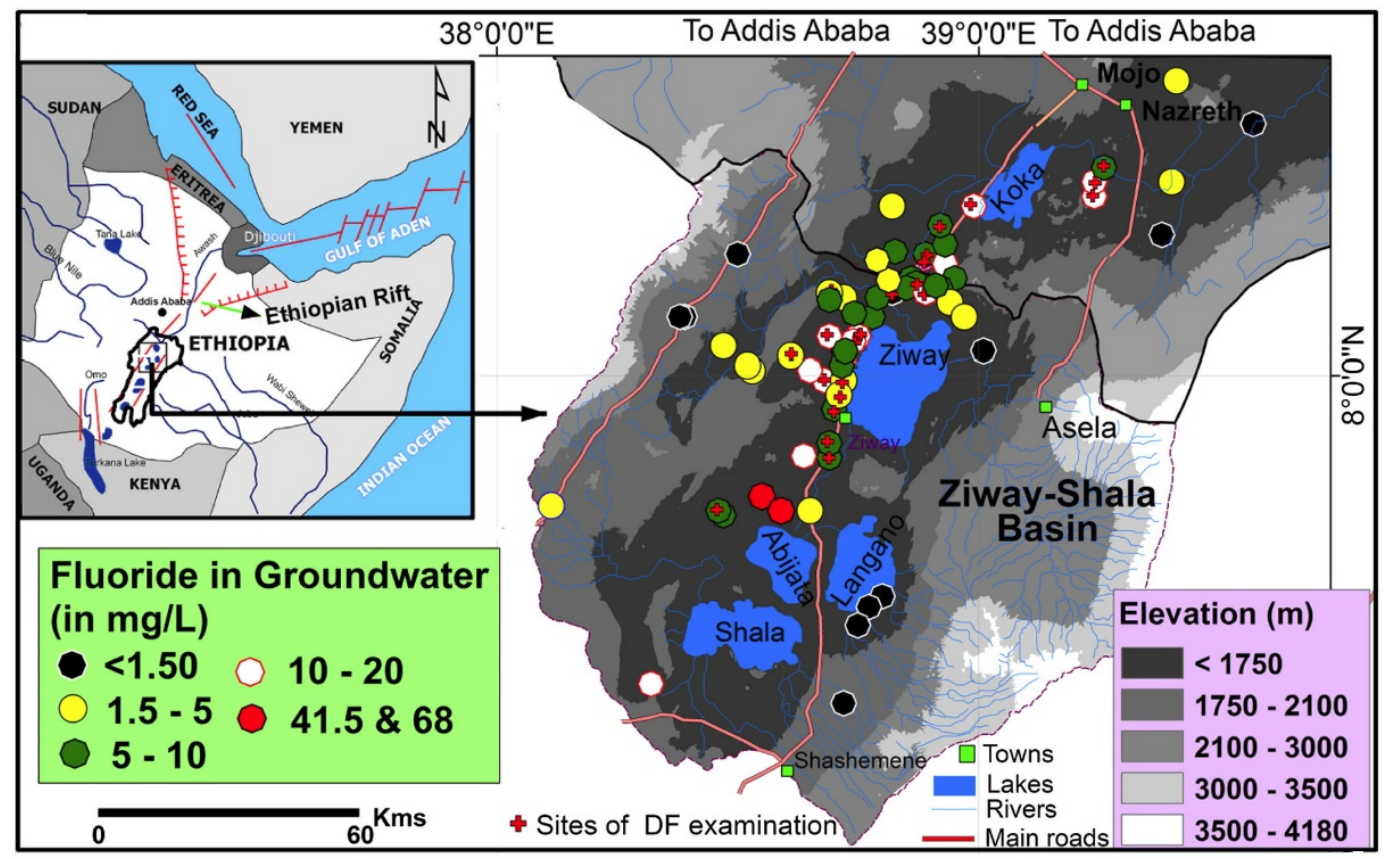

Figure 1. Groundwater sampling sites with measured $\mathrm{F}^{-}$concentrations and sites that received DF examination. Modified from Rango et al. (2012). 


\subsubsection{Study population and dental fluorosis examination}

Clinical examination of DF was conducted in children drinking water from 33 of the 94 sampled wells (selected to represent a wide range of $\mathrm{F}^{-}$concentrations ranging between 1 and $18 \mathrm{mg} / \mathrm{L}$ ) (Fig. 1). Upon arrival in a village, the study team spread the word with key village informants that children were being recruited for a health study related to water quality. Children were then enrolled if they volunteered (with parental consent) to participate in the study by coming to local clinics, schools, or other village-level meeting sites. Only children between 10 and 15 years old $(n=491)$ were included in the sample in order to examine DF in permanent teeth. Furthermore only lifelong residents drinking from community wells that were constructed before their birth were enrolled. Given the lack of viable alternative sources, these children's exposure to $\mathrm{F}^{-}$should thus have been relatively stable and consistent throughout the critical period of enamel development as well as formation of permanent teeth.

The dental health impact of $\mathrm{F}^{-}$was evaluated using the TF Index (Thylstrup and Fejerskov, 1978), an epidemiological index that best correlates the clinical appearance of various degrees of fluorosis to pathologic change in the enamel and has a range for severe forms of DF that is more sensitive than alternatives such as Dean's index (Fejerskov et al., 1996). TF scores are grouped into the following categories: healthy translucent teeth (score of 0), mild DF (scores of 1 and 2), moderate DF (scores of 3 and 4), and severe DF (scores between 5 and 9). Scores of 1-4 correspond to increasing white opaque areas on the enamel. The severe form begins with focal pitting, followed by increasing pitting on the white opaque enamel that progresses to confluent pitting, and then total loss of enamel and tooth deformation (Fig. 2). Prior to DF examination, the vestibular (buccal) surfaces of teeth were cleaned and dried with sterile gauze, and the teeth were examined under natural light.

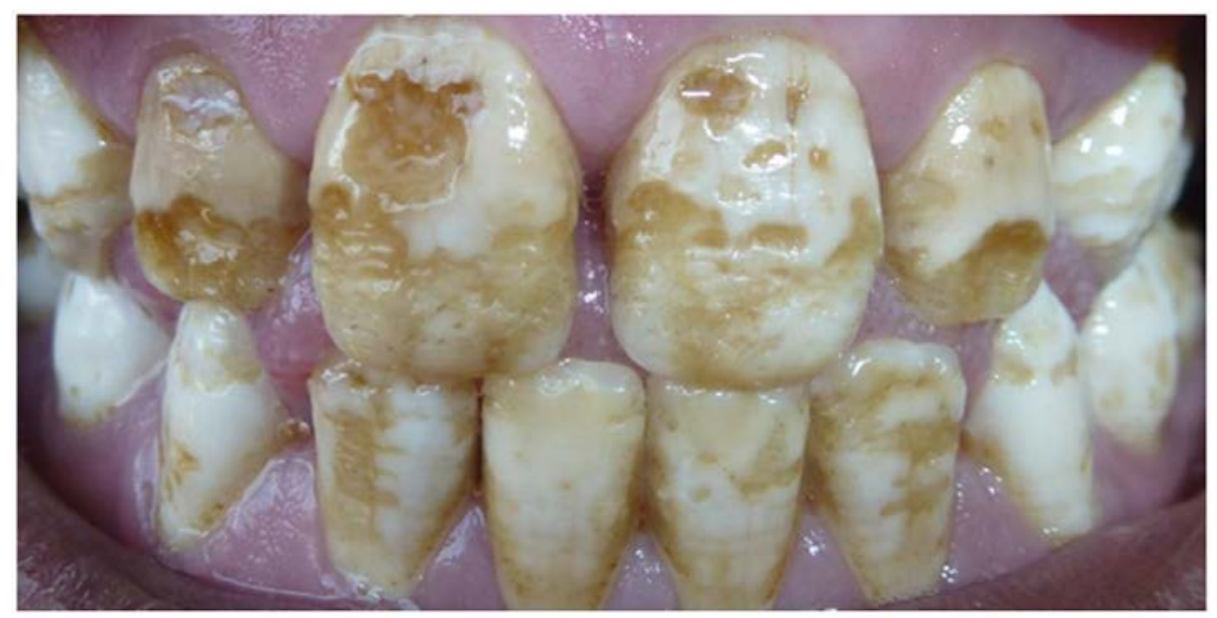

Figure 2. Severe enamel fluorosis in a 14-year-old boy born and raised with $13 \mathrm{mg} / \mathrm{L}^{-}$of $\mathrm{F}^{-}$ in groundwater in the MER. TF scores of the upper and the lower jaw from left to right are $(7,8,9,8,8,6)$ and $(5,7,7,5,5,7,6,5)$, respectively. 
A total of 12,526 upper and lower jaw teeth were examined in the 491 examined individuals. Teeth with cavities or any sign of dental caries were excluded from the examination. The reliability of the TF scores for incisor teeth was reassessed by a separate examiner using photos of the teeth; this comparison yielded scores showing an acceptable level of agreement with those of the field examiner with no significant difference $\left(R^{2}=0.8 ; p>0.05\right)$.

All examined teeth were categorized in accordance with their mineralization and age of eruption, as either early-erupting (i.e., incisors and first molars) or late-erupting (i.e., canines, premolars, and second molars). They were also grouped into posterior (i.e., premolars, first molars, and second molars) and anterior teeth (i.e., incisors and canines). These groupings were used for the analyses of DF severity with respect to the $\mathrm{F}^{-}$in the groundwater and urine.

\subsubsection{Urine sample collection and analyses}

For $\mathrm{F}^{-}$exposure assessment, we tested urinary $\mathrm{F}^{-}$concentrations from first morning void urine samples of 156 children (a subset randomly selected from the larger group of 491 children) selected from 17 community wells representing a wide range of $\mathrm{F}^{-}$concentrations ( 1 to $18 \mathrm{mg} / \mathrm{L}$ ). Urine samples were collected in acid-washed $60 \mathrm{~mL}$ ultra-cleaned polyethylene bottles. A semi-quantitative urinalysis test using Siemens Multistix 8SGH (results were confirmed with a $\mathrm{pH}$ meter) was carried out in-situ to measure urinary $\mathrm{pH}$. The $\mathrm{F}^{-}$ concentration in urine was also measured using ISE following the procedure used for the water samples described above. Quality control was conducted using freeze-dried urine reference material (SERO210705; LGC Standards) concurrently with urine samples of the individuals. The accuracy of ISE $\mathrm{F}^{-}$measurements for both urine and water standards ranged from $98 \%$ to $102.5 \%$ relative to the standard. No $\mathrm{F}^{-}$concentrations were below the detection limit of the $\mathrm{F}^{-}$electrode $(0.02 \mathrm{mg} / \mathrm{L})$.

\subsection{4. $F^{-}$in milk}

In addition to the aforementioned analyses, fresh milk samples from cows were collected from villages with well water containing low to high $\mathrm{F}^{-}$and were tested for $\mathrm{F}^{-}$concentration. In these communities, cows often drink water from both rivers and wells. The $\mathrm{F}^{-}$concentration in cow's milk was measured in-situ using ISE following a procedure similar to that used for the water samples.

\subsection{Surveys}

A pre-tested and translated survey questionnaire was conducted in face-to-face interviews with sample children and their parents. It included questions about sex, age, place of birth, exposure duration, drinking water sources, water intake per day, groundwater well drilling year, toothpaste use, infant formula consumption, breast feeding history, and basic health survey data on nutritional status and perceptions of health risks.

For the nutritional assessments, we took several anthropometric measurements and asked mothers' to report on the breastfeeding and infant formula intake of the sample children. Specifically, the anthropometric measurements included height and weight to calculate body mass index (BMI; weight $(\mathrm{kg}) /$ height $\left(\mathrm{m}^{2}\right)$ ), mid-upper arm circumference (MUAC), and subscapular skinfold thickness (SST) measured for the nondominant arm. 
Finally, the average water intake in a day was estimated with reference to a standard container used by the households in this region.

\subsection{Statistical analysis}

The database construction and basic statistical analyses were conducted using Microsoft Excel 2010 and the IBM SPSS statistical package version 22. Descriptive analyses were carried out using quartiles, means and standard deviations for continuous variables. Bivariate analyses were performed using t-tests. StataSE version 11 was used for multivariate regression analyses of the effects of $\mathrm{F}^{-}$(in water and urine) on TF scores, controlling for potential modifiers (such as age, sex, BMI, and breast feeding duration). The statistical significance was set at $p<0.05$.

\subsection{Ethical considerations}

The research design was conducted with the ethical approval (Protocol No. A0045 and A0741) of the Institutional Review Board (IRB) at Duke University. Permission to carry out the survey was also obtained from Addis Ababa University in Ethiopia and from local water bureaus in the study region. All children (and their parents) who willingly participated in the survey were provided with a written informed consent prior to enrollment and participation in the study. The anonymity of investigated subjects has been maintained.

\section{Results}

\subsection{General characteristics}

The average age of children was 12 years; approximately half $(52.3 \% ; n=257)$ of the study participants were female (Table 1). Based on the WHO (2000) classification of BMI, most children were categorized as underweight with the 75th percentile falling below $17.4 \mathrm{~kg} / \mathrm{m}^{2}$ and a mean BMI of $16.4 \pm 2.15 \mathrm{~kg} / \mathrm{m}^{2}$. The mean water consumption per day in children was $1.2 \pm 0.4 \mathrm{~L}$. The $\mathrm{F}^{-}$concentrations in the groundwater and urine samples ranged between 1.1 and $18 \mathrm{mg} / \mathrm{L}$ and 1.1 and $39.8 \mathrm{mg} / \mathrm{L}$, respectively. The interquartile ranges of the estimated daily $\mathrm{F}^{-}$intake per day, $\mathrm{F}^{-}$intake per body weight per day, and urinary $\mathrm{F}^{-}$concentration were $6.7-12.2 \mathrm{mg} /$ day, $0.19-0.37 \mathrm{mg} / \mathrm{kg}$ bw/day, and $6.7-15.6 \mathrm{mg} / \mathrm{L}$, respectively. Nearly all children $(97 \% ; n=476)$ thus ingested an estimated daily amount of $\mathrm{F}^{-}$that exceeded the U.S. EPA's NOAEL value for F- $(0.06 \mathrm{mg} / \mathrm{kg}$ bw/day). 


\begin{tabular}{|c|c|c|c|c|c|c|c|}
\hline & \multirow[b]{2}{*}{$\mathrm{N}$} & \multirow[b]{2}{*}{ Min } & \multicolumn{3}{|c|}{ Percentiles } & \multirow[b]{2}{*}{ Max } & \multirow[b]{2}{*}{ Mean \pm SD } \\
\hline & & & 25 th & 50th & 75th & & \\
\hline \multicolumn{8}{|l|}{ Anthropometric measures } \\
\hline Age & 491 & 10.0 & 11.0 & 12.0 & 13.0 & 15.0 & $12.1 \pm 1.6$ \\
\hline Weight (kg) & 487 & 19.0 & 28.0 & 32.0 & 39.0 & 61.0 & $34.1 \pm 8.9$ \\
\hline Height (m) & 487 & 1.15 & 1.34 & 1.42 & 1.52 & 1.83 & $1.42 \pm 0.1$ \\
\hline $\mathrm{BMI}\left(\mathrm{kg} / \mathrm{m}^{2}\right)$ & 486 & 11.2 & 15.0 & 16.2 & 17.4 & 25.8 & $16.4 \pm 2.2$ \\
\hline MUAC (cm) & 484 & 10.0 & 17.0 & 18.5 & 21.0 & 28.0 & $19.0 \pm 2.6$ \\
\hline $\mathrm{SST}(\mathrm{mm})$ & 354 & 7.0 & 10.0 & 10.0 & 12.0 & 22.0 & $10.5 \pm 1.8$ \\
\hline \multicolumn{8}{|l|}{ Water $\mathrm{F}^{-}$concentrations } \\
\hline Water intake (liter/day) & 491 & 0.33 & 1.0 & 1.0 & 1.33 & 2.70 & $1.15 \pm 0.4$ \\
\hline $\mathrm{F}^{-}$in groundwater $(\mathrm{mg} / \mathrm{L})$ & 491 & 1.10 & 5.4 & 8.14 & 11.1 & 18.0 & $8.7 \pm 3.9$ \\
\hline $\mathrm{F}^{-}$intake (mg/day) & 491 & 0.54 & 6.7 & 8.77 & 12.2 & 36.0 & $9.8 \pm 5.4$ \\
\hline Dose (mg/kg bw/day) & 491 & 0.01 & 0.19 & 0.27 & 0.37 & 1.03 & $0.23 \pm 0.2$ \\
\hline \multicolumn{8}{|l|}{ Milk $\mathrm{F}^{-}$concentrations } \\
\hline $\mathrm{F}^{-}$in cow's milk & 15 & 0.042 & 0.059 & 0.087 & 0.11 & 0.13 & $0.09 \pm 0.03$ \\
\hline \multicolumn{8}{|l|}{ Urinary measures } \\
\hline $\mathrm{F}^{-}$in urine $(\mathrm{mg} / \mathrm{L})$ & 156 & 1.10 & 6.74 & 11.5 & 15.6 & 39.8 & $12.1 \pm 7.3$ \\
\hline Urinary $\mathrm{pH}$ & 156 & 4.85 & 5.19 & 6.0 & 6.48 & 8.50 & $5.9 \pm 0.85$ \\
\hline \multicolumn{8}{|l|}{ Breast feeding history } \\
\hline Breast milk alone (months) & 355 & 1.0 & 6.0 & 6.0 & 6.0 & 12.0 & $6.3 \pm 2.2$ \\
\hline Start drinking water (months) & 356 & 1.0 & 6.0 & 6.0 & 7.0 & 12.0 & $6.8 \pm 2.3$ \\
\hline Stop breast feeding (months) & 355 & 3.0 & 24.0 & 24.0 & 24.0 & 60.0 & $24.8 \pm 8.6$ \\
\hline
\end{tabular}

The measured urinary $\mathrm{pH}$ range was $4.9-8.5$, with a mean of $5.9 \pm 0.85$. The $\mathrm{F}^{-}$concentration in the cow's milk samples ranged between 0.04 and $0.13 \mathrm{mg} / \mathrm{L}$, with a mean of 0.09 $\pm 0.03 \mathrm{mg} / \mathrm{L}$. Among the sample children, the average length of exclusive breastfeeding duration from birth was between 6 and 7 months; by 25 months on average, children had ceased breastfeeding. Only $5 \%(n=18)$ of the interviewed children consumed infant formula during childhood, and only two reported using toothpaste.

\subsection{Fluoride in groundwater and dental fluorosis}

Evidence of DF (TF scores $\geq 1$ ) was observed in at least one tooth in all 491 children, indicating $100 \%$ DF prevalence for individuals drinking from the 33 groundwater wells containing $\mathrm{F}^{-}$levels of 1.1 to $18 \mathrm{mg} / \mathrm{L}$ (Table 2). Severe dental health impacts were found in $45 \%$ of the examined teeth, exhibited varying degrees of loss of the enamel (TF scores of 5 to 9). The positive associations between $\mathrm{F}^{-}$in drinking water and the prevalence of DF or mean severity of TF scores appear linear at first (Fig. 3A and B) but then level off with similar prevalence or severity (mostly TF scores of 5 and 6 ) in the teeth of individuals who consume drinking water with $\mathrm{F}^{-}$concentration above $\sim 6 \mathrm{mg} / \mathrm{L}$ ( $72 \%$ of the children examined in this study). Among all examined teeth within the subgroup of children consuming groundwater with concentrations above $6 \mathrm{mg} / \mathrm{L}, 43.7 \%$ were assigned TF scores of 5 and 6 . 


\begin{tabular}{|c|c|c|c|c|c|c|c|c|c|c|c|c|c|c|}
\hline \multirow[b]{2}{*}{ Community name } & \multirow[b]{2}{*}{$\begin{array}{l}\mathrm{F}^{-} \text {in ground- } \\
\text { water }(\mathrm{mg} / \mathrm{L})\end{array}$} & \multicolumn{10}{|c|}{ Percent of teeth with each TF score } & \multirow{2}{*}{$\begin{array}{c}\text { Mean TF } \\
\text { scores of } \\
\text { all teeth }\end{array}$} & \multirow[b]{2}{*}{$\begin{array}{c}\text { Number of } \\
\text { children }\end{array}$} & \multirow[b]{2}{*}{$\begin{array}{c}\text { Number } \\
\text { of teeth }\end{array}$} \\
\hline & & 0 & 1 & 2 & 3 & 4 & 5 & 6 & 7 & 8 & 9 & & & \\
\hline Oda & 1.06 & 40.0 & 41.3 & 15.0 & 3.8 & 0 & 0 & 0 & 0 & 0 & 0 & $0.8 \pm 0.1$ & 3 & 80 \\
\hline Sera & 1.61 & 43.5 & 30.6 & 14.0 & 8.1 & 1.6 & 2.3 & 0 & 0 & 0 & 0 & $1.0 \pm 0.9$ & 17 & 444 \\
\hline Wedesha & 2.92 & 32.3 & 21.5 & 24.7 & 13.3 & 3.7 & 3.5 & 1.0 & 0 & 0 & 0 & $1.5 \pm 1.0$ & 16 & 405 \\
\hline Beyimo & 3.70 & 49.3 & 24.9 & 12.3 & 9.9 & 2.7 & 0.8 & 0 & 0 & 0 & 0 & $0.9 \pm 0.8$ & 15 & 373 \\
\hline Hezbawe & 3.73 & 6.10 & 15 & 19.6 & 16.8 & 14.3 & 15.7 & 5.4 & 6.8 & 0.4 & 0 & $3.2 \pm 1.4$ & 11 & 279 \\
\hline Gebeba Rasa & 4.00 & 17.2 & 19.7 & 19.3 & 16.8 & 16.0 & 5.7 & 2.5 & 2.5 & 0.4 & 0 & $2.4 \pm 1.4$ & 10 & 244 \\
\hline Edokontolla & 5.20 & 12.8 & 4.8 & 7.4 & 8.2 & 23.1 & 20.5 & 14.4 & 8.0 & 0.8 & 0 & $3.9 \pm 1.2$ & 17 & 376 \\
\hline Tuchidako & 5.24 & 1.6 & 11.7 & 10.5 & 16.6 & 28.4 & 19.1 & 10.3 & 1.9 & 0 & 0 & $3.6 \pm 1.0$ & 18 & 450 \\
\hline Hafa Rosa & 5.27 & 8.8 & 7.7 & 17.9 & 25.0 & 21.7 & 14.8 & 2.5 & 1.6 & 0 & 0 & $3.0 \pm 1.2$ & 14 & 364 \\
\hline Haleku & 5.40 & 0 & 2.1 & 2.4 & 10.7 & 16.8 & 30.3 & 15.6 & 12.5 & 6.1 & 3.4 & $5.2 \pm 1.3$ & 12 & 327 \\
\hline Wergaweshengula & 5.42 & 10.8 & 7.2 & 16.8 & 30.5 & 19.2 & 7.2 & 7.2 & 1.2 & 0 & 0 & $2.9 \pm 1.3$ & 7 & 167 \\
\hline Elecametramofa & 7.20 & 8.5 & 4.6 & 16.5 & 18.1 & 16.1 & 26.0 & 5.4 & 3.6 & 1.0 & 0.2 & $3.5 \pm 1.3$ & 8 & 497 \\
\hline Jido & 7.20 & 1.8 & 0.9 & 10.0 & 16.8 & 15.0 & 22.3 & 13.2 & 15.5 & 3.6 & 0.9 & $4.7 \pm 1.5$ & 19 & 220 \\
\hline Orgacho & 7.23 & 16.8 & 5.2 & 12.7 & 24.8 & 21.8 & 11.4 & 3.4 & 3.9 & 0 & 0 & $2.9 \pm 1.2$ & 17 & 440 \\
\hline Choreke & 7.24 & 2.5 & 1.4 & 3.3 & 5.7 & 37.0 & 26.8 & 10.9 & 10.5 & 1.8 & 0 & $4.6 \pm 1.2$ & 18 & 488 \\
\hline Tejitu & 7.84 & 0 & 4.3 & 3.9 & 11.7 & 19.9 & 46.3 & 13.0 & 0.9 & 0 & 0 & $4.4 \pm 0.7$ & 9 & 231 \\
\hline Berta & 7.96 & 0 & 0.2 & 1.5 & 6.1 & 14.2 & 36.6 & 21.1 & 17.2 & 2.3 & 0.8 & $5.4 \pm 0.7$ & 19 & 507 \\
\hline Negaligne & 8.14 & 4.8 & 3.4 & 11.2 & 10.8 & 20.5 & 19.3 & 12.2 & 13.3 & 4.6 & 0 & $4.4 \pm 1.5$ & 20 & 502 \\
\hline Bofo & 8.60 & 0.6 & 0.9 & 4.6 & 8.9 & 18.3 & 35.6 & 22.0 & 8.9 & 0.4 & 0 & $4.9 \pm 1.0$ & 20 & 542 \\
\hline Tuchigabriel & 8.73 & 0 & 0 & 2.9 & 5.8 & 19.6 & 51.4 & 18.8 & 1.4 & 0 & 0 & $4.5 \pm 0.3$ & 4 & 111 \\
\hline Aneno & 8.77 & 0 & 3.6 & 9.1 & 19.4 & 19.4 & 30.9 & 15.2 & 2.4 & 0 & 0 & $4.1 \pm 1.1$ & 6 & 167 \\
\hline Wonji (Camp-3) & 9.66 & 0 & 0.6 & 5.0 & 11.8 & 8.7 & 45.3 & 16.1 & 12.4 & 0 & 0 & $4.7 \pm 0.8$ & 7 & 188 \\
\hline Chore & 9.88 & 0.8 & 2.8 & 7.9 & 9.3 & 23.1 & 19.8 & 17.0 & 16.8 & 2.4 & 0 & $4.7 \pm 1.1$ & 20 & 494 \\
\hline Sarete & 10.4 & 4.4 & 4.4 & 6.2 & 5.6 & 23.9 & 24.5 & 15.3 & 11.5 & 3.8 & 0.3 & $4.6 \pm 1.1$ & 14 & 339 \\
\hline Tuchigrabona & 10.7 & 0 & 0 & 1.3 & 13.9 & 26.0 & 33.6 & 11.3 & 13.4 & 0.4 & 0 & $4.8 \pm 0.7$ & 9 & 238 \\
\hline Wulumbula & 10.8 & 4.7 & 4 & 10.2 & 14.9 & 19.6 & 21.5 & 13.2 & 9.2 & 1.5 & 1.2 & $4.2 \pm 1.2$ & 27 & 683 \\
\hline
\end{tabular}


Rango et Al., SCIENCE of the TOtal ENVIRONMENT 496 (2014)

\begin{tabular}{|c|c|c|c|c|c|c|c|c|c|c|c|c|c|c|}
\hline Gura & 11.1 & 10.3 & 2.9 & 6.2 & 9.9 & 19.1 & 19.7 & 16.2 & 12.7 & 2.9 & 0.2 & $4.2 \pm 1.3$ & 21 & 487 \\
\hline Wodera & 11.2 & 4.8 & 12.2 & 6.3 & 4.4 & 19.6 & 22.5 & 17.0 & 11.1 & 2.2 & 0.0 & $4.2 \pm 1.5$ & 12 & 289 \\
\hline Woyogabriel & 11.3 & 0 & 0 & 7.6 & 4.1 & 14.9 & 50.8 & 19.5 & 1.6 & 1.6 & 0 & $4.8 \pm 0.6$ & 15 & 371 \\
\hline Wonji (camp-7) & 13.0 & 1.9 & 3.1 & 4.5 & 7.3 & 13.2 & 23.7 & 11.3 & 20.6 & 11.5 & 2.8 & $4.4 \pm 0.8$ & 6 & 165 \\
\hline Wegea & 13.2 & 8.4 & 6.3 & 11.2 & 13.4 & 24.4 & 24.2 & 9.2 & 2.4 & 0.2 & 0.1 & $3.6 \pm 1.4$ & 34 & 890 \\
\hline Wonji (camp-9) & 13.3 & 0.2 & 2.2 & 4.0 & 8.9 & 13.3 & 32.2 & 10.9 & 23.5 & 4.0 & 0.8 & $5.3 \pm 1.2$ & 22 & 527 \\
\hline Cheleleki & 18.0 & 1.3 & 1.3 & 2.2 & 5.2 & 12.8 & 30.6 & 14.7 & 21.7 & 8.1 & 2.2 & $5.5 \pm 1.2$ & 24 & 641 \\
\hline
\end{tabular}



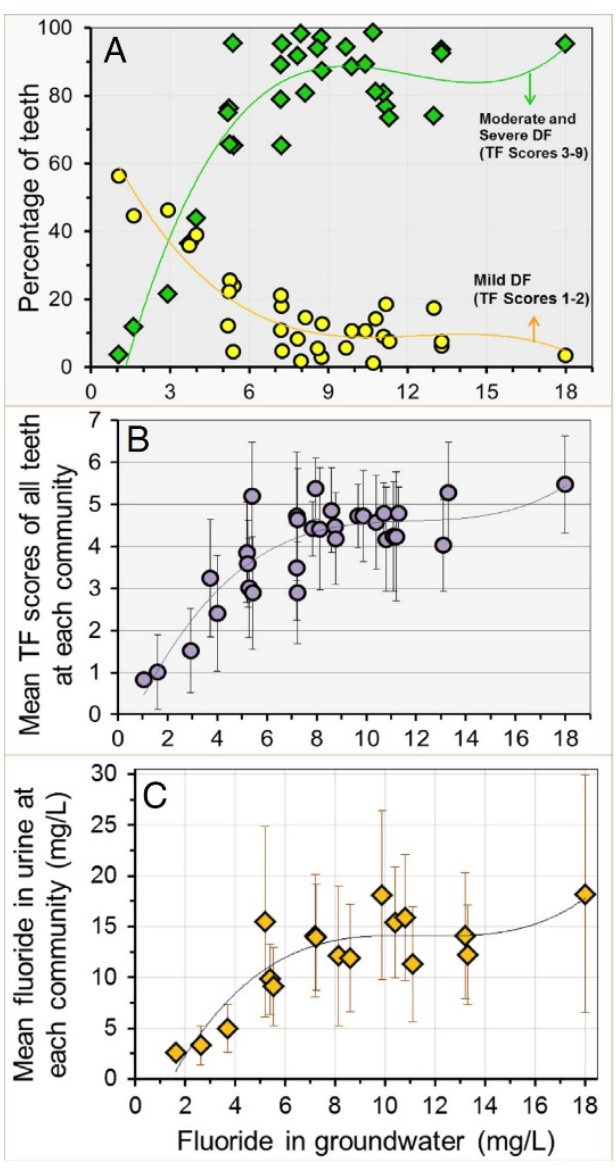

Figure 3. (A) Percentage of teeth with DF (mild and moderate-severe); (B) severity of DF; and $(\mathrm{C})$ children's urinary $\mathrm{F}^{-}$concentration; as a function of $\mathrm{F}^{-}$concentrations in groundwater (See also Table 4). Each point is a community-level average. Percentage and severity of teeth with mild-moderate-severe (TF scores $\geq 1$ ) and $\mathrm{F}^{-}$concentrations in groundwater best fit by a 3rd order polynomial model. (A) Percentage of teeth with $\mathrm{DF}=0.035 \mathrm{~F}^{3}-1.3$ $\mathrm{F}^{2}+15.7 \mathrm{~F}+38.4 ; R^{2}=0.85$, and (B) DF severity $=0.0031 \mathrm{~F}^{3}-0.11 \mathrm{~F}^{2}+1.34 \mathrm{~F}-0.82 ; R^{2}=0.78$, and $(\mathrm{C})$ the $\mathrm{F}^{-}$relationship in groundwater and urine is best fit by a 3rd order polynomial model $\left[\mathrm{F}^{-}\right.$in urine $\left.=0.014 \mathrm{~F}^{3}-0.49 \mathrm{~F}^{2}+5.6 \mathrm{~F}-7.1 ; R^{2}=0.77\right]$; where $\mathrm{F}^{\text {is }} \mathrm{F}^{-}$concentration in groundwater. Vertical lines indicate standard deviations from the mean within each community.

Most of the children exposed to groundwater $\mathrm{F}^{-}$concentrations below $1.6 \mathrm{mg} / \mathrm{L}$ had healthy teeth (TF scores of 0 ) in some of their dentition; such scores were assigned to about $9 \%$ of all the teeth examined in the study. The mild, moderate, and severe DF prevalence in all examined teeth was $17 \%, 29 \%$, and $45 \%$, respectively. Furthermore, $\sim 11 \%$ of the teeth exhibited TF scores of 7, 8, and 9. Thus, an assessment of the prevalence of aesthetically significant fluorosis (TF scores of $\geq 3$ ) in the teeth of all children was $74 \%$. Referencing the relationship shown in Fig. 3A, at the $\mathrm{F}^{-}$level equivalent to the WHO drinking water stand- 
ard of $1.5 \mathrm{mg} / \mathrm{L}, 53 \%$ and $5 \%$ of the teeth exhibited a mild and moderate form of DF, respectively. At the $\mathrm{F}^{-}$level of $2 \mathrm{mg} / \mathrm{L}$, equivalent to the U.S. EPA's SMCL standard, $47 \%$ of teeth showed mild DF, with the remaining teeth displaying moderate $(14.7 \%)$ to severe (2.8\%; predominantly with TF score of 5) enamel damage. At F- level of $4 \mathrm{mg} / \mathrm{L}$, equivalent to the U.S. EPA's MCLG standard, $28.5 \%$ of teeth showed mild DF, with the remaining teeth displaying moderate (28\%) to severe (26\%; predominantly with TF scores of 5 to 7 ) enamel damage. Thus, while the WHO standard predominantly corresponds to the mild form of dental impact in this population, neither of the U.S. EPA standards appears to guarantee a safe $\mathrm{F}^{-}$threshold in the study population. The prevalence of moderate and severe DF approaches zero only at $\mathrm{F}^{-}$concentrations below $1.2 \mathrm{mg} / \mathrm{L}$ and $1.8 \mathrm{mg} / \mathrm{L}$, respectively.

The severity of DF also varies depending on tooth type and group (Table 3). Molars and incisors were more severely affected as compared to canines and premolars $(p<0.001)$. Severity of DF was significantly higher in the upper jaw teeth relative to the lower ones, with average TF scores of $4.1 \pm 1.7$ and $3.8 \pm 1.7$, respectively $(p<0.01)$. TF scores in earlyerupting and posterior teeth were also greater in the upper jaw than in the lower jaw $(p<0.01)$.

\begin{tabular}{|c|c|c|c|c|c|c|}
\hline & \multirow[b]{2}{*}{$\mathrm{N}$} & \multicolumn{3}{|c|}{ Percentiles } & \multirow[b]{2}{*}{ Max } & \multirow[b]{2}{*}{ Mean \pm SD } \\
\hline & & 25th & 50 th & 75th & & \\
\hline \multicolumn{7}{|l|}{ Type of tooth } \\
\hline All central incisors & 491 & 3.0 & 4.0 & 5.0 & 8.0 & $4.0 \pm 1.6$ \\
\hline All incisors & 491 & 3.0 & 4.0 & 5.0 & 8.0 & $3.9 \pm 1.6$ \\
\hline All canines & 490 & 2.0 & 4.0 & 4.7 & 7.5 & $3.5 \pm 1.9$ \\
\hline All premolars & 491 & 2.1 & 4.1 & 5.1 & 8.6 & $3.7 \pm 2.0$ \\
\hline All molars & 481 & 3.8 & 5.3 & 6.0 & 8.8 & $4.8 \pm 1.9$ \\
\hline \multicolumn{7}{|l|}{ Group of teeth } \\
\hline Upper jaw early erupting & 491 & 3.3 & 4.7 & 5.5 & 8.2 & $4.4 \pm 1.7$ \\
\hline Upper jaw late erupting & 491 & 2.2 & 4.1 & 5.1 & 8.4 & $3.8 \pm 1.9$ \\
\hline Posterior upper jaw & 491 & 2.8 & 4.6 & 5.4 & 8.8 & $4.1 \pm 1.9$ \\
\hline Posterior lower jaw & 491 & 2.5 & 4.4 & 5.5 & 9.0 & $4.0 \pm 2.0$ \\
\hline Anterior upper jaw & 491 & 2.8 & 4.2 & 5.0 & 8.3 & $4.0 \pm 1.7$ \\
\hline Anterior lower jaw & 491 & 2.3 & 3.8 & 4.7 & 7.3 & $3.5 \pm 1.6$ \\
\hline All early erupting & 491 & 3.2 & 4.4 & 5.3 & 7.7 & $4.1 \pm 1.6$ \\
\hline All late erupting & 491 & 2.3 & 4.1 & 5.2 & 8.2 & $3.8 \pm 1.9$ \\
\hline All upper jaw & 491 & 2.9 & 4.4 & 5.2 & 8.0 & $4.1 \pm 1.7$ \\
\hline All lower jaw & 491 & 2.8 & 4.1 & 5.0 & 7.7 & $3.8 \pm 1.7$ \\
\hline All teeth & 491 & 2.9 & 4.3 & 5.1 & 7.8 & $3.9 \pm 1.7$ \\
\hline
\end{tabular}

a. Note that minimum TF scores were zero for all tooth types and teeth groups. Fewer observation in canines and molars in some individuals is because of dental caries or not erupted teeth. 
Table 4. Distribution of $\mathrm{F}^{-}$in groundwater, urinary $\mathrm{F}^{-}$concentration, $\mathrm{pH}$ in urine, and $\mathrm{TF}$ scores of all teeth

\begin{tabular}{ccccc}
\hline $\begin{array}{c}\text { F- in } \\
\text { groundwater }\end{array}$ & $\mathrm{F}^{-}$in urine & pH in urine & TF scores of all teeth & $\begin{array}{c}\text { Number of } \\
\text { children }\end{array}$ \\
\hline 1.6 & $2.6 \pm 0.8(1.4-4.2)$ & $6.1 \pm 1.1(5.0-8.5)$ & $1.2 \pm 1.0(0-3.3)$ & 9 \\
2.6 & $3.3 \pm 1.9(1.2-6.9)$ & $5.9 \pm 1.4(5.0-8.5)$ & $1.0 \pm 0.8(0.12-2.7)$ & 8 \\
3.7 & $5.0 \pm 2.4(1.1-7.6)$ & $5.0 \pm 0.0(5.0-5.0)$ & $0.6 \pm 0.2(0.3-0.8)$ & 8 \\
5.2 & $15.5 \pm 9.4(4.4-29.2)$ & $6.4 \pm 0.6(6-7.5)$ & $4.4 \pm 0.8(3.1-5.4)$ & 6 \\
5.4 & $9.8 \pm 3.5(4.9-17.2)$ & $5.8 \pm 0.5(5.2-6.6)$ & $5.2 \pm 1.3(3.7-7.8)$ & 12 \\
5.5 & $9.1 \pm 3.9(3.1-16.2)$ & $5.4 \pm 0.6(5.0-6.5)$ & $3.2 \pm 0.9(2.4-4.8)$ & 7 \\
7.2 & $14.1 \pm 6.0(6.4-25.6)$ & $6.5 \pm 1.0(4.9-7.5)$ & $3.5 \pm 1.3(1.5-5)$ & 10 \\
7.2 & $13.9 \pm 5.2(8.4-24.9)$ & $5.9 \pm 0.4(5.2-6.6)$ & $4.2 \pm 1.3(1.1-6.4)$ & 10 \\
8.1 & $12.1 \pm 6.9(3.7-28.1)$ & $6.4 \pm 0.7(6.0-8.0)$ & $3.8 \pm 1.3(1.9-6.6)$ & 9 \\
8.6 & $11.9 \pm 5.3(2.1-24.1)$ & $5.9 \pm 0.4(4.9-6.5)$ & $5.1 \pm 0.7(4.1-5.9)$ & 12 \\
9.9 & $18.1 \pm 8.3(9.7-34.8)$ & $6.4 \pm 0.9(5.0-8.5)$ & $5.2 \pm 0.9(3.3-6.2)$ & 10 \\
10.4 & $15.4 \pm 5.5(5.6-25.5)$ & $5.6 \pm 0.8(4.9-6.9)$ & $4.7 \pm 1.2(2.3-6.7)$ & 10 \\
10.8 & $15.9 \pm 6.2(10.1-28.0)$ & $6.4 \pm 0.8(6.0-8.0)$ & $4.6 \pm 1.5(1.8-6.2)$ & 9 \\
11.1 & $11.3 \pm 5.7(5.2-18.9)$ & $6.4 \pm 1.2(5.0-8.0)$ & $4.3 \pm 1.5(1.9-6.5)$ & 6 \\
13.2 & $14.1 \pm 6.2(8.6-22.2)$ & $5.8 \pm 0.9(5.0-7.5)$ & $2.6 \pm 1.9(0.7-5.5)$ & 7 \\
13.3 & $12.2 \pm 4.9(4.2-20.8)$ & $5.5 \pm 0.3(5.1-6.2)$ & $5.3 \pm 1.4(2.2-7.1)$ & 14 \\
18.0 & $18.2 \pm 11.7(6.6-39.8)$ & $5.9 \pm 0.9(5.0-7.5)$ & $5.6 \pm 1.6(2.9-7.5)$ & 9 \\
\hline
\end{tabular}

a. Values are expressed as mean $\pm \mathrm{SD}$ (minimum-maximum).

Means of DF severity in all tooth types and group of teeth were not significantly different between male and female children $(p<0.05)$. Age was positively related to overall TF scores $(p<0.01)$. BMI, SST, and MUAC did not show a significant correlation with TF scores. Duration of breastfeeding and age of onset of groundwater consumption were not associated with DF severity. The lack of sensitivity of DF severity to these factors is likely due to the lack of variation in these parameters among children included in the survey. The results of these mean comparisons were also generally consistent with findings from multivariate regression analysis, which did not indicate consistent patterns of significance for these potential modifiers of DF outcomes (see Supplemental material, Table S1).

\subsection{Fluoride in groundwater, and urine, and dental fluorosis}

The mean urinary $\mathrm{F}^{-}$concentration of all 156 children was $12.1 \pm 7.3 \mathrm{mg} / \mathrm{L}$ (range: $1.1-39.8$ $\mathrm{mg} / \mathrm{L}$ ), whereas the average $\mathrm{F}^{-}$concentration in groundwater was $8.5 \pm 4.1 \mathrm{mg} / \mathrm{L}$ (range: 1.1-18 mg/L). Notably, at lower $\mathrm{F}^{-}$exposures $(<\sim 6 \mathrm{mg} / \mathrm{L})$, the $\mathrm{F}^{-}$exposure and mean urinary $\mathrm{F}^{-}$concentration at each community seem to fit a linear relationship, but the concentration tends to level off at higher groundwater $\mathrm{F}^{-}$concentrations (Fig. 3C). A similar relationship is observed between $\mathrm{F}^{-}$exposure and DF outcomes (Fig. 3B). Despite this relationship, there is considerable variation in the individual specific urinary $\mathrm{F}^{-}$concentration and the respective groundwater $\mathrm{F}^{-}$concentration to which they are exposed (Fig. 4). 


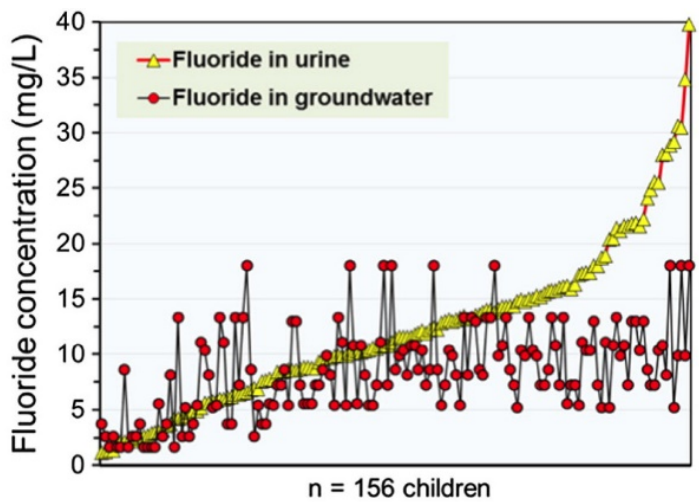

Figure 4. The association between $\mathrm{F}^{-}$concentration in groundwater and the respective urinary $\mathrm{F}^{-}$concentration for each child in the sample, ordered by urinary concentration.

\subsection{Urinary fluoride concentrations after defluoridation}

We tested urinary $\mathrm{F}^{-}$concentrations in children from one community (Bofo site) where a pilot groundwater defluoridation project was being applied as part of remediation of the DF epidemic in the MER. As a result of the treatment, the measured $\mathrm{F}^{-}$concentration in groundwater (originally $9 \mathrm{mg} / \mathrm{L}$ ) was reduced by about $50 \%$ to $4.5 \mathrm{mg} / \mathrm{L}$ on average. Though we do not have pretreatment baseline measures of urinary $\mathrm{F}^{-}$concentration, we measured lower urinary $\mathrm{F}^{-}$concentration among tested subjects $(n=8)$ in the 10th month $(7.3 \pm 2.0 \mathrm{mg} / \mathrm{L})$ compared to the $1 \mathrm{st}$ month $(11.7 \pm 2.2 \mathrm{mg} / \mathrm{L})$ following the treatment (Fig. 5). This indicates that $\mathrm{F}^{-}$assessment in urine could remain a useful tool for monitoring $\mathrm{F}^{-}$ exposure from other potential sources after defluoridation interventions. The persistence of relatively higher than expected $\mathrm{F}^{-}$levels in urine suggests the possibility of other sources of $\mathrm{F}^{-}$intake (e.g., locally grown food) or mobilization of $\mathrm{F}^{-}$from skeletal tissues following a reduction in the level of $\mathrm{F}^{-}$intake in treated groundwater as demonstrated in other studies (e.g., Whitford, 1999).

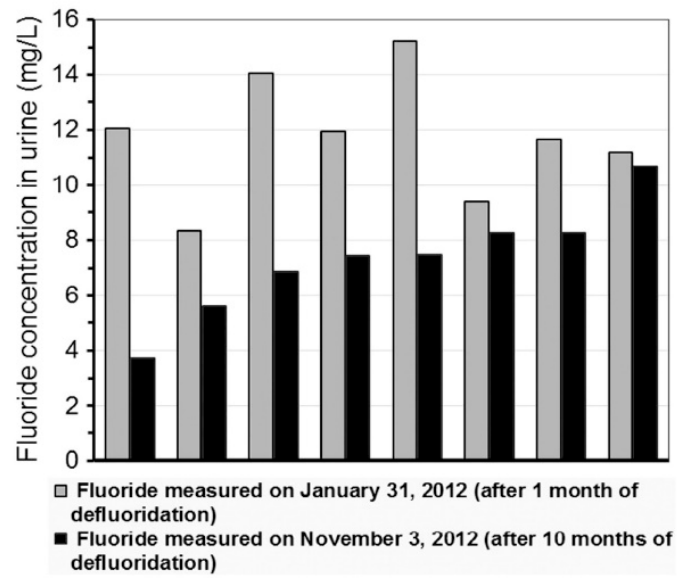

Figure 5. Change in children's $(n=8)$ urinary $\mathrm{F}^{-}$concentration after defluoridation. 


\section{Discussion}

This paper reports on findings from a cross-sectional study investigating the association between $\mathrm{F}^{-}$exposure in groundwater, prevalence (and severity) of $\mathrm{DF}$, and concentration of $\mathrm{F}^{-}$excreted in urine. We limit risk of confounding by restricting the sample to a group of children (aged between 10 and 15) who are lifelong residents of communities with limited access to alternative water supplies. Among children drinking water from wells with concentrations above $6 \mathrm{mg} / \mathrm{L}$, we find very high prevalence and severity of DF. We also find that groundwater $\mathrm{F}^{-}$on the one hand, and $\mathrm{DF}$ and urinary concentrations of $\mathrm{F}^{-}$on the other, are linearly and positively correlated up to this threshold. Beyond this threshold, both markers of high $\mathrm{F}^{-}$exposure appear to level off. The study adds to previous research that has considered the relationship between groundwater $\mathrm{F}^{-}$and DF. Finally, we provide some of the first evidence on $\mathrm{F}^{-}$concentrations measured in urine for this region. As far as we know, no other studies in $\mathrm{F}^{-}$-endemic areas have linked such a wide range of $\mathrm{F}^{-}$exposures to detailed analysis of DF in children.

Our study clarifies the relationship between $\mathrm{F}^{-}$exposure and DF. Up to the $\mathrm{F}^{-}$threshold of $\sim 6 \mathrm{mg} / \mathrm{L}$ in drinking water, a linear relationship $\left(R^{2}=0.4 ; p<0.001\right)$ between $\mathrm{F}^{-}$and $\mathrm{DF}$ appears valid. When $\mathrm{F}^{-}$exceeds $\sim 6 \mathrm{mg} / \mathrm{L}$, however, the DF prevalence (and severity) levels off. The leveling off is most likely due to the fact that at $\sim 6 \mathrm{mg} / \mathrm{L}$ the enamel is damaged as much as it can be clinically observed in most of the children. This indicates that the DF outcomes gradually become less pronounced with increased $\mathrm{F}^{-}$exposures above this apparent threshold. Across the range of concentrations covered in this study, we found a very high prevalence of severe DF ( $45 \%$ of examined teeth), characterized by pitting and structural damage to teeth (TF scores $\geq 5$ ). The mean TF scores at the lowest $(1.1 \mathrm{mg} / \mathrm{L})$ and highest $(18 \mathrm{mg} / \mathrm{L}) \mathrm{F}^{-}$concentrations in these communities were $0.8 \pm 0.1$ and $5.5 \pm 1.2$, respectively; the later DF severity is consistent with another study conducted in high $\mathrm{F}^{-}$areas (9-14 mg/L) in the MER (Wondwossen et al., 2006).

We also found a similarly positive but nonlinear association (leveling off above $\sim 6 \mathrm{mg} / \mathrm{L}$ of $\mathrm{F}^{-}$in drinking water) between $\mathrm{F}^{-}$concentrations in groundwater and mean urinary $\mathrm{F}^{-}$ concentration of children in each community. In addition, the majority $(97 \% ; n=152)$ of the children tested for urinary $\mathrm{F}^{-}$had higher daily $\mathrm{F}^{-}$intake (range: $1.1-30 \mathrm{mg} /$ day) from drinking water than the recommended daily dietary intake of $\mathrm{F}^{-}(2.5 \mathrm{mg} /$ day $)$ for children aged $\geq 10$ years (U.S. NRC, 1989). It is interesting to note that a similar study of Tibetan children ( 8 to 15 years) found urinary $\mathrm{F}^{-}$concentration of $1.8 \mathrm{mg} / \mathrm{L}$ corresponding to an average $5.4 \mathrm{mg} /$ day F- intake that resulted in a mild form of DF (Cao et al., 1996). In our study, most children's teeth showed mild DF at urinary $\mathrm{F}^{-}$concentrations below $3 \mathrm{mg} / \mathrm{L}$. We also found that a large proportion $(90 \% ; n=140)$ of children had urinary $\mathrm{F}^{-}$above $3 \mathrm{mg} / \mathrm{L}$, with some levels reaching up to $39.8 \mathrm{mg} / \mathrm{L}$. These higher concentrations were predominantly associated with moderate to severe DF.

Children retain more $\mathrm{F}^{-}$during growth and development of calcified tissues than later in life when net bone formation slows (Whitford, 1996, 1999). Considering the excessive and prolonged steady $\mathrm{F}^{-}$exposure in the study population, we cannot rule out the possibility that calcified tissues for many individuals drinking high $\mathrm{F}^{-}$ground water are close to saturation with respect to this element, such that $\mathrm{F}^{-}$uptake by calcified tissue is reduced 
and leads to a more significant proportion of $\mathrm{F}^{-}$being excreted mainly through the kidneys. In this condition, the $\mathrm{F}^{-}$excretion could exceed $80 \%$ of the total $\mathrm{F}^{-}$intake (Myers, 1978).

Despite the similarity in the relationship between groundwater $\mathrm{F}^{-}$concentration and community-level averages for DF or urinary $\mathrm{F}^{-}$concentration, the latter outcomes were highly variable among the children within a community. Several factors may influence this variation in DF outcomes and urinary concentrations among the children, including genetic variation in susceptibility to enamel fluorosis, differences in total exposure from diets, variation in diets (e.g., food rich in protein and/or micronutrients), amounts of water consumed, urinary flow rate and urinary $\mathrm{pH}$ (Whitford, 1990; Yoder et al., 1998; U.S. NRC, 2006). Similar to Whitford (1990), we found that the urinary $\mathrm{F}^{-}$concentration in MER children was positively correlated with urinary $\mathrm{pH}$, though in our study this correlation was not significant $(p>0.05)$. Evidence from animal studies meanwhile suggests that individual genetic variability might contribute to susceptibility to enamel fluorosis (Everett et al., 2002; Carvalho et al., 2009).

The urinary $\mathrm{F}^{-}$concentrations recorded in this research should account for $\mathrm{F}^{-}$intake from dietary sources. We observed that the local communities in the MER heavily depend on subsistence agriculture and foods produced from locally grown crops (Malde et al., 2011; Rango et al., 2012). Very few children have access to infant formula, and thus $\mathrm{F}^{-}$intake from infant formula is likely to be small or negligible in the majority of these children. In addition, almost none of the surveyed children use toothpaste, suggesting that the children were not exposed to $\mathrm{F}^{-}$through incidental ingestion of toothpaste. Previous research has estimated that young children ( $<5$ years of age) living in the study area and consuming water with $\mathrm{F}^{-}$concentrations of $2 \mathrm{mg} / \mathrm{L}$ and $14 \mathrm{mg} / \mathrm{L}$ ingest about $2.3 \mathrm{mg} /$ day and 4.2 $\mathrm{mg} /$ day, respectively, from foods prepared using these water sources (Malde et al., 2004). In this study area, the total daily $\mathrm{F}^{-}$intake in children consuming water with $2 \mathrm{mg} / \mathrm{L}$ is mainly derived from food (63\%), while children consuming high- $\mathrm{F}^{-}$water $(14 \mathrm{mg} / \mathrm{L})$ get most of their $\mathrm{F}^{-}$through beverages (60\%) (Malde et al., 2003). More recently, Malde et al. (2011) found that the daily $\mathrm{F}^{-}$intake in children aged 2 to 5 years from water sources with $1.95 \mathrm{mg} / \mathrm{L}$ and $14.4 \mathrm{mg} / \mathrm{L}$ of $\mathrm{F}^{-}$, was $34 \%$ and $50 \%$ of their total daily $\mathrm{F}^{-}$intake of $3.1 \pm 0.6$ $\mathrm{mg} /$ day and $15.7 \pm 2.9 \mathrm{mg} /$ day (or $0.08 \mathrm{mg} / \mathrm{kg}$ bw/day, and $0.57 \mathrm{mg} / \mathrm{kg}$ bw/day), respectively (Malde et al., 2011). Similar calculations for $\mathrm{F}^{-}$intake per $\mathrm{kg}$ of body weight are consistent with two villages in our study with similar $\mathrm{F}^{-}$concentration of $1.6 \mathrm{mg} / \mathrm{L}$ and 13.4 $\mathrm{mg} / \mathrm{L}$, for which we estimated daily F- intake of $2.2 \pm 1.1$, and $15.4 \pm 7.5 \mathrm{mg} /$ day (or 0.07 and $0.46 \mathrm{mg} / \mathrm{kg} \mathrm{bw} /$ day). Another recent work from the study area has shown that the total $\mathrm{F}^{-}$intake from drinking water alone among adults consuming groundwater with 1,3 , and $11.5 \mathrm{mg} / \mathrm{L}$ of $\mathrm{F}^{-}$was $33 \%, 58 \%$, and $86 \%$, respectively (Dessalegne and Zewege, 2013). Our communities likely had similar dietary habits to both of these, so that the $\mathrm{F}^{-}$contribution from food that is measured in these studies provides a potentially valid estimate of the amount of $\mathrm{F}^{-}$individuals ingest from such sources.

Other dietary factors may also play a role. For example, earlier findings from the same region have suggested that children who consume cows' milk in the MER are somewhat less likely to have severe DF (on average about 10\% lower TF scores; $p<0.05$ ) (Rango et al., 2012; Kravchenko et al., 2014). As part of the current study, we measured the concentration of $\mathrm{F}^{-}$in 15 samples of cows' milk and found it to be very low (mean: $0.09 \pm 0.03 \mathrm{mg} / \mathrm{L}$; range: 
0.04-0.13 mg/L), consistent with results from another study conducted in Canada (mean $\mathrm{F}^{-}$concentration: $0.041 \mathrm{mg} / \mathrm{kg}$; range: $0.007-0.086 \mathrm{mg} / \mathrm{kg}$ ) (Dabeka and McKenzie, 1995). A study in the Kenyan Rift Valley among nursing mothers consuming high $\mathrm{F}^{-}$drinking water ( $9 \mathrm{mg} / \mathrm{L}$ ) similarly found negligible levels of $\mathrm{F}^{-}$in breast milk, ranging from 0.011 to 0.073 $\mathrm{mg} / \mathrm{L}$ (Opinya et al., 1991). The low $\mathrm{F}^{-}$level in milk, coupled with its high nutritional value (i.e., high calcium and magnesium), may provide protection against dental and skeletal fluorosis. In general, future studies in the MER should focus on further clarifying the total $\mathrm{F}^{-}$intake from food and water sources, and consequently uptake by the skeleton, using methods such as 24-hour urinary excretion, and taking account of milk consumption.

The $\mathrm{F}^{-}$levels in MER groundwater in our study sites are much higher than the WHO drinking water limit of $1.5 \mathrm{mg} / \mathrm{L}$ and are also higher than the U.S. EPA's primary standard of $4 \mathrm{mg} / \mathrm{L}$. While the U.S. EPA has set this standard in order to minimize the risk of skeletal fluorosis, some studies have shown that mild skeletal effects may occur below $4 \mathrm{mg} / \mathrm{L}$ (Cauley et al., 1995; Ayoob and Gupta, 2006). Further investigation in these locations may provide important evidence on other adverse health conditions attributable to excessive $\mathrm{F}^{-}$ exposure, such as skeletal effects, which is not very well documented in the MER. For example, a study in Tanzania (part of the EARS) found SF in children (juvenile SF) exposed to high-F- (up to $35 \mathrm{mg} / \mathrm{L}$ ) concentrations in the groundwater (Jarvis et al., 2013). This finding suggests the potential for occurrence of similar juvenile SF cases in the MER region.

Furthermore, whereas surveys in the U.S. have found low prevalence of DF among children aged $12-15$ years at the EPA standard (e.g., 37\% very mild to mild DF, and $3.6 \%$ moderate to severe) (Beltran-Aguilar et al., 2010), we observed severe DF (enamel pitting) in $26 \%$ of children's teeth at this level. In milder forms of DF, it is only possible to observe changes in the enamel; however, the dentin can be affected in more severe cases (Fejerskov et al., 1996) such that protection against decay and infection is compromised. This can cause tooth sensitivity (TS) and affect eating, drinking, and breathing through the mouth (Mine et al., 2011; Zhang et al., 2014). Moderate and severe DF is also associated with increased caries and psychological and social impacts (Wondwossen et al., 2006). Thus, severe DF affects tooth function and overall quality of life of afflicted individuals, rather than simply having cosmetic effects.

\subsection{Limitations of the study}

We selected communities representing the range of groundwater $\mathrm{F}^{-}$concentrations and recruited a volunteer sample rather than conducting a random population-based sampling. The study thus considers only a limited age range and a range of concentrations to which individuals in the region are exposed. Due to lack of time-series measurements, water quality sampling was conducted during the dry season to minimize seasonal variations arising from varying recharge across wells. Still, we do not expect significant variation in the water chemistry in the deep (>50 m) aquifer system underlying the MER (Rango et al., 2013), from which the majority of study households obtain their drinking water. In addition, though groundwater was the sample population's primary water source, alternative water sources with low $\mathrm{F}^{-}$(e.g., surface waters during rainy season, or piped water from neighboring towns) may be available and used intermittently by some households. In addition, although fluorosis occurs as a result of cumulative $\mathrm{F}^{-}$exposure, our survey only 
measured DF prevalence at a single point in time; we therefore do not observe how the severity of DF in individuals evolves over time. Similarly, due to time and logistical constraints imposed by the dispersed nature of the study communities, we obtained only early morning spot urine samples, and thus reported $\mathrm{F}^{-}$concentrations from these samples rather than excretion over a 24-hour urine, which provides a more reliable estimate of $\mathrm{F}^{-}$ exposure than spot urine (Zohouri et al., 2013). Finally, data on breastfeeding and consumption of infant formula were obtained from the children's mothers' retrospective selfreports, which may vary in accuracy.

\title{
5. Conclusion
}

A significant proportion of the children examined in this study drinks water from sources with high levels of $\mathrm{F}^{-}$, excretes urine with high levels of $\mathrm{F}^{-}$, and suffers from dental health damage in the form of severe DF. The results show nonlinear positive relationships between $\mathrm{F}^{-}$exposure, urinary $\mathrm{F}^{-}$, and $\mathrm{DF}$ in children. In drinking water samples collected during the study, we did not find a minimum $\mathrm{F}^{-}$concentration threshold below which $\mathrm{DF}$ was absent. However, we estimated two NOAELs, corresponding to $\mathrm{F}^{-}$concentration thresholds of 1.2 and $1.8 \mathrm{mg} / \mathrm{L}$ in drinking water, as the lowest concentrations associated with no occurrence of moderate and severe DF in children's dentition, respectively. The findings from this study should be useful for planning preventive public health interventions such as education and behavior changes, or selecting sites from highly affected areas of the MER for promotion of water defluoridation and substitution. In addition, measurement of $\mathrm{F}^{-}$concentration in urine provides a useful tool for evaluating human exposure to $\mathrm{F}^{-}$that could help in monitoring the success of such interventions. We recommend that governments and nongovernmental organizations use this information for risk assessment and design of $\mathrm{F}^{-}$exposure mitigation to better safeguard the health of populations in the MER and in other areas with high prevalence of fluorosis.

\begin{abstract}
Abbreviations: bw, body weight; BMI, body mass index; DF, dental fluorosis; EARS, East African Rift System; F-, fluoride; IRB, Institutional Review Board; ISE, Ion Selective Electrode; mg/L, milligram per liter; mg/kg bw/day, milligram per kilogram body weight per day; MER, Main Ethiopian Rift; MCLG, Maximum-Contaminant-Level Goal; MUAC, mid-upper arm circumference; NOAEL, No-Observed-Adverse-Effects-Level; SMCL, Secondary-Maximum-Contaminant-Level Goal; SST, subscapular skinfold thickness; TISAB, Total Ionic Strength Adjuster Buffer; TF Index, Thylstrup and Fejerskov Index; U.S. NRC, U.S. National Research Institute; U.S. EPA, U.S. Environmental Protection Agency; WHO, World Health Organization.
\end{abstract}

Disclaimer: The findings and conclusions in this report are those of the authors and do not necessarily represent the official position of the funding sources.

Conflict of interest: The authors declare they that have no actual or potential competing financial interests.

Authors' contributions: Tewodros Rango: Designed the study concept; conducted field work, analytical data analysis, and interpretation; and wrote the manuscript. 
Avner Vengosh: Designed the study concept and critically revised the manuscript for important intellectual content.

Marc Jeuland: Interpreted data and critically revised the manuscript for important intellectual content.

Redda Tekle-Haimanot, Erika Weinthal, Julia Kravchenko, Christopher Paul, and Peter McCornick: Assisted with field work and revised the manuscript for important intellectual content.

Disclosure statement: Tewodros Rango, Avner Vengosh, Marc Jeuland, Redda Tekle-Haimanot, Erika Weinthal, Julia Kravchenko, Christopher Paul, and Peter McCornick declare no actual or potential conflict of interest including financial support of the submitted work, as well as no persona, or other relationships with organizations or people that could inappropriately influence the work that occurred since 2010. All authors are independent from funders. There are no other relationships or activities that could appear to have influenced the submitted work.

Acknowledgments and funding: We are grateful to all the children and parents who participated in this study, and the local water bureaus for their help in recruiting them as well as guiding us during the field work. The authors would like to express sincere gratitude to the Duke Global Health Institute, the Nicholas Institute for Environmental Policy Solutions, and Duke University Provost's PFIRST (Problem-Focused Interdisciplinary Research-Scholarship Teams) at Duke University for the financial support for the study. We are grateful to Professor Gary M. Whitford (Department of Oral Biology, Georgia Regents University, Augusta, Georgia, USA) for his helpful review and suggestions for the improvement of this paper. We also thank the anonymous reviewers for their constructive critiques that improved the quality of the manuscript.

\section{References}

Amini M, Mueller K, Karim CA, Thomas R, Majib A, Klaus NM, et al. Statistical modeling of global geogenic fluoride contamination in groundwater. Environ Sci Technol 2008; 42:3662-68.

Ayoob S, Gupta A. Fluoride in drinking water: a review on the status and stress effects. Crit Rev Environ Sci Technol 2006; 36:433-87.

Beltran-Aguilar ED, Barker L, Dye BA. Prevalence and severity of dental fluorosis in the United States, 1999-2004. NCHS Data Brief 2010; 53:1-8.

Cao J, Bai X, Zhao Y, Liu J, Zhou D, Fang S, et al. The relationship of fluorosis and brick tea drinking in Chinese Tibetans. Environ Health Perspect 1996; 104:1340-43.

Carvalho JG, Leite AL, Yan D, Everett ET, Whitford GM, Buzalaf MA. Influence of genetic background on fluoride metabolism in mice. J Dent Res 2009; 88:1054-58.

Cauley JA, Murphy PA, Riley TJ, Buhari AM. Effects of fluoridated drinking water on bone mass and fractures: the study of osteoporotic fractures. J Bone Miner Res 1995; 10: 1076-86.

Chorowicz J. The East African Rift System. J Afr Earth Sci 2005; 43:379-410.

Czarnowski W, Wrześniowska K, Krechniak J. Fluoride in drinking water and human urine in Northern and Central Poland. Sci Total Environ 1996; 19:177-84.

Dabeka RW, McKenzie AD. Survey of lead, cadmium, fluoride, nickel, and cobalt in food composites and estimation of dietary intakes of these elements by Canadians in 1986-1988. J AOAC Int 1995; 78:897-909.

Den Besten PK. Dental fluorosis: its use as a biomarker. Adv Dent Res 1994; 8:105-10. 
Dessalegne M, Zewege F. Daily dietary fluoride intake in rural villages of the Ethiopian Rift Valley. Toxicol Environ Chem 2013; 95:1056-68.

Ding Y, Gao Y, Sun H, Han H, Wang W, Ji X, et al. The relationships between low levels of urine fluoride on children's intelligence, dental fluorosis in endemic fluorosis areas in Hulunbuir, Inner Mongolia, China. J Hazard Mater 2011; 186:1942-46.

Ekstrand J, Fomon SJ, Ziegler EE, Nelson SE. Fluoride pharmacokinetics in infancy. Pediatr Res 1994; 35:157-63.

Everett ET, McHenry MA, Reynolds N, Eggertsson H, Sullivan J, Kantmann C, et al. Dental fluorosis: Variability among different inbred mouse strains. J Dent Res 2002; 81: 794-98.

Fejerskov O, Ekstrand J, Burt BA. Fluoride in dentistry. 2nd ed. Copenhagen: Munksgaard; 1996.

Fomon SJ, Ekstrand J, Ziegler EE. Fluoride intake and prevalence of dental fluorosis: trends in fluoride intake with special attention to infants. J Public Health Dent 2000; 60: 131-39.

Forte FD, Moimaz SA, Sampaio FC. Urinary fluoride excretion in children exposed to fluoride toothpaste and to different water fluoride levels in a tropical area of Brazil. Braz Dent J 2008; 19:21418.

Heintze SD, Bastos JRM, Bastos R. Urinary fluoride levels and prevalence of dental fluorosis in three Brazilian cities with different fluoride concentrations in the drinking water. Community Dent Oral Epidemiol 1998; 26:316-23.

Hong L, Levy SM, Broffitt B, Warren JJ, Kanellis MJ, Wefel JS, et al. Timing of fluoride intake in relation to development of fluorosis on maxillary central incisors. Community Dent Oral Epidemiol 2006; 34:299-309.

Jarvis HG, Heslop P, Kisima J, Gray WK, Ndossi G, Maguire A, et al. Prevalence and aetiology of juvenile skeletal fluorosis in the south-west of the Hai district, Tanzania community-based prevalence and case-control study. Trop Med Int Health 2013; 18:222-29.

Kravchenko J, Rango T, Akushevichc I, Atlaw B, McCornick P, Merola B, Paul C, Weinthal E, Harrison C, Vengosh A, Jeuland M. The effect of non-fluoride factors on risk of dental fluorosis: Evidence from rural populations of the Main Ethiopian Rift. Sci Total Environ 2014; 488-489:595606.

Malde MK, Maage A, Macha E, Julshamn K, Bjorvatn K. Fluoride content in selected food items from five areas in East Africa. J Food Compos Anal 1997; 10:233-45.

Malde MK, Zerihun L, Julshamn K, Bjorvatn K. Fluoride intake in children living in a high-fluoride area in Ethiopia. Intake through beverages. Int J Paediatr Dent 2003; 13(3): 27-34.

Malde M, Zerihun L, Julshamn K, Bjorvatn K. Fluoride, calcium and magnesium intake in children living in a high-fluoride area in Ethiopia. Intake through food. Int J Paediatr Dent 2004; 14(3):16774.

Malde MK, Scheidegger R, Julshamn K, Bader HP. Substance flow analysis - a case study for fluoride exposure through food and beverages in young children living in Ethiopia. Environ Health Perspect 2011; 119:579-84.

Mine OT, Yener O, Tugba S, Yonca S, Kirzioglu FY. Tooth sensitivity in fluorotic teeth. Eur J Dent $2011 ; 5: 273-80$.

Myers HM. Fluorides and dental fluorosis. Monographs in oral science. Philadelphia, PA: Karger Publishers; 1978.

Opinya GN, Bwibo N, Valderhaug J, Birkeland JM, Lökken P. Intake of fluoride and excretion in mothers' milk in a high fluoride (9 ppm) area in Kenya. Eur J Clin Nutr 1991; 45:37-41. 
Rango T, Kravchenko J, Atlaw B, McCornick PG, Jeuland M, Merola B, et al. Groundwater quality and its health impact: an assessment of dental fluorosis in rural inhabitants of the Main Ethiopian Rift. Environ Int 2012; 43:37-47.

Rango T, Vengosh A, Dwyer G, Bianchini G. Mobilization of arsenic and other naturally occurring contaminants in groundwater of the Main Ethiopian Rift aquifers. Water Res J 2013. http://dx.doi .org/10.1016/j.watres.2013.07.002 [Online 10 July 2013].

Reimann C, Bjorvatn K, Frengstad B, Melaku Z, Tekle-Haimanot R, Siewers U. Drinking water quality in the Ethiopian section of the East African Rift Valley I-data and health aspects. Sci Total Environ 2003; 311:65-80.

Ruiz-Payan A, Ortiz M, Duarte-Gardea M. Determination of fluoride in drinking water and in urine of adolescents living in three counties in Northern Chihuahua Mexico using a fluoride ion selective electrode. Microchem J 2005; 81:19-22.

Singh B, Gaur S, Garg VK. Fluoride in drinking water and human urine in Southern Haryana, India. J Hazard Mater 2007; 144:147-51.

Srikanth R, Gautam A, Jaiswal SC, Singh P. Urinary fluoride as a monitoring tool for assessing successful intervention in the provision of safe drinking water supply in five fluoride-affected villages in Dhar district, Madhya Pradesh, India. Environ Monit Assess 2013; 185:2343-50.

Tekle-Haimanot R. Study of fluoride and fluorosis in Ethiopia with recommendations on appropriate defluoridation technologies. Consultancy report, UNICEF-Ethiopia. Faculty of medicine, Addis Ababa University; 2005.

Tekle-Haimanot, Haile. Chronic alcohol consumption and the development of skeletal fluorosis in a fluoride endemic area of the Ethiopian Rift Valley. J Water Res Prot 2014; 6:149-55.

Tekle-Haimanot R, Fekadu A, Bushra B. Endemic fluorosis in the Ethiopian Rift Valley. Trop Geogr Med 1987; 39:209-17.

Thylstrup A, Fejerskov O. Clinical appearance of dental fluorosis in permanent teeth in relation to histologic changes. Community Dent Oral Epidemiol 1978; 6:315-28.

U.S. CDC (U.S. Centers for Disease Control, Prevention). Achievements in public health, 1900-1999: fluoridation of drinking water to prevent dental caries. MMWR 1999; 48: 933-40. [Available at http://www.cdc.gov/mmwr/preview/mmwrhtml/mm4841a1.htm].

U.S. CDC (U.S. Centers for Disease Control, Prevention). Recommendations for using fluoride to prevent and control dental caries in the United States. MMWR 2001; 50: 1-42.

U.S. DHHS (US Department of Health and Human Services). Public Health Service Committee to coordinate environmental health and related programs. Review of fluoride: benefits and risk. Washington, DC: Public Health Service; 1991.

U.S. EPA (U.S. Environmental Protection Agency). Integrated Risk Information System, Fluorine (soluble fluoride, CASRN 7782-41-4); 2002.

U.S. NRC (U.S. National Research Council). Recommended dietary allowances. 10th ed. Washington, DC: National Academy Press; 1989.

U.S. NRC (U.S. National Research Council). Fluoride in drinking water: a scientific review of EPA's standards. Committee on fluoride in drinking water, National Research Council. Washington, DC: The National Academies Press; 2006. [Available: http://www.nap.edu/catalog.php?record_id=11571 (accessed 7 July 2013)].

Villa A, Anabalon M, Cabezas L. The fractional urinary fluoride excretion in young children under stable fluoride intake conditions. Community Dent Oral Epidemiol 2000; 28: 344-55.

Wang C, Gao Y, Wang W, Zhao L, Zhang W, Han H, et al. A national cross-sectional study on effects of fluoride-safe water supply on the prevalence of fluorosis in China. BMJ Open 2012; 2:1-11. 
Whitford GM. The physiological and toxicological characteristics of fluoride. J Dent Res 1990; 69:539_ 49.

Whitford GM. Intake and metabolism of fluoride. Adv Dent Res 1994; 8:5-14.

Whitford GM. The metabolism and toxicity of fluoride. Monographs in oral science. Basel: Karger; 1996.

Whitford GM. Fluoride metabolism and excretion in children. J Public Health Dent 1999; 59:224-28.

WHO. Obesity: preventing and managing the global epidemic. Report of a WHO consultation. WHO Technical Report Series 894Geneva: World Health Organization; 2000.

Wondwossen F, Astrom AN, Bjorvatn K, Bardsen A. The relationship between dental caries and dental fluorosis in areas with moderate- and high-fluoride drinking water in Ethiopia. Community Dent Oral Epidemiol 2004; 32(5):337-44.

Wondwossen F, Astrøm AN, Bjorvatn K, Bardsen A. Sociodemographic and behavioural correlates of severe dental fluorosis. Int J Paediatr Dent 2006; 16:95-103.

World Health Organization (WHO). Fluoride in drinking-water. In: Fawell J, Bailey K, Chilton J, Dahi E, Fewtrell L, Magara Y, editors. London, UK: IWA Publishing 1900222965; 2006. [Available: http://whqlibdoc.who.int/publications/2006/ 9241563192_eng.pdf (accessed 7 July 2013)].

Yoder KM, Mabelya L, Robison VA, Dunipace AJ, Brizendine EJ, Stookey GK. Severe dental fluorosis in Tanzanian population consuming water with negligible fluoride concentration. Community Dent Oral Epidemiol 1998; 26:382-93.

Zhang Y, Cheng R, Cheng G, Zhang X. Prevalence of dentine hypersensitivity in Chinese rural adults with dental fluorosis. Oral Rehabil 2014; 41:289-95.

Zohouri FV, Rugg-Gunn AJ. Total fluoride intake and urinary excretion in 4-year-old Iranian children residing in low-fluoride areas. Br J Nutr 2000; 83:15-25.

Zohouri FV, Walls R, Teasdale L, Landes D, Steen IN, Moynihan P, et al. Fractional urinary fluoride excretion of 6-7-year-old children attending schools in low-fluoride and naturally fluoridated areas in the UK. Br J Nutr 2013; 109:1903-909. 


\section{Supplemental Material}

Supplemental Material, Table S1. Relationship between $\mathrm{F}^{-}$in groundwater and average TF scores for all teeth and early-erupting teeth only, and urinary $\mathrm{F}^{-}$concentration, controlling for potential mediating factors ${ }^{a}$

\begin{tabular}{lccc}
\hline All teeth & $\begin{array}{c}\text { Early erupting } \\
\text { teeth }\end{array}$ & $\begin{array}{c}\text { Urinary } \mathbf{F}^{-} \\
\text {concentration }\end{array}$ \\
\hline In(F-) & $1.72^{*}$ & $1.79^{*}$ & $6.38^{*}$ \\
Female & 0.24 & 0.25 & 0.74 \\
Age & 0.04 & -0.03 & 0.94 \\
& 0.13 & 0.14 & 0.99 \\
MUAC & $0.24^{*}$ & 0.07 & -0.40 \\
& 0.06 & 0.07 & 0.46 \\
constant & 0.02 & -0.01 & 0.00 \\
& 0.04 & 0.05 & 0.24 \\
& $-2.85^{*}$ & -0.13 & 3.40 \\
N & 0.80 & 0.82 & 5.43 \\
R-squared & 0.40 & 0.36 & 156 \\
\hline
\end{tabular}

a. Models including duration of breastfeeding or age of onset of drinking groundwater (and interactions with $\mathrm{F}^{-}$ levels expressed in log-term) did not lead to substantive changes in results or improvements in model fit. Standard errors were shown on second line. ${ }^{*}=p<0.01$. 